\title{
Forensic Accounting on Corporate Governance Maturity mediated by Internal Audit: A Conceptual Overview
}

\author{
Ali Rehman \\ Internal Audit Department, \\ A’Sharqiyah University, \\ 400, Ibra, Oman \\ ali.rehman@ asu.edu.om
}

\author{
Fathyah Hashim \\ Graduate School of Business, \\ Universiti Sains Malaysia, \\ 11800 USM, Penang, Malaysia \\ fathashim@usm.my
}

\begin{abstract}
Identification and development of forensic accounting as an organization's essential intangible asset has been traced as an immense vital essence that can influence corporate governance maturity. This paper attempts to integrate relevant empirical research and literature to extend the intended potentials of forensic accounting on corporate governance maturity particularly in public listed companies in Oman. Moreover, this paper will identify the role of forensic accounting as preventive measure rather than a detective control which is at present widely understood. The paper also proposes that internal audit poses a mediating role between forensic accounting and corporate governance maturity by linking professional theory and agency theory in its relationship. Since the existing literature provides less evidence that attempt to observe the influence of forensic accounting on corporate governance maturity, this paper offers and calls a promising proposition for future research.
\end{abstract}

Keywords- Forensic Accounting; Corporate Governance Maturity; Auditors; Fraud

\section{INTRODUCTION}

It is widely understood and as mentioned by many scholars that poor corporate governance leads to fraud, misappropriation of assets and dissatisfied shareholders [1]. It is also stated by [2], that no country is invulnerable to fraud. History and recent past is filled with events where organizations demonstrated poor corporate governance and end up either in filing bankruptcy or incorporate huge losses in their financial statements (Vinita, 2005).

Vinita [3] and Fernando [4] stated that recent frauds are not only due to the failure of corporate governance but also demonstrated poor accounting practices which were not detected by the conventional auditors. Controlling ownership and minority shareholders protection is difficult through conventional corporate control mechanism, i.e., it requires process enhancement which can be provided by Forensic Accounting [5]. Besides, auditors have denied the role for identifying fraud which had created an expectation gap between shareholders and auditors [6]. This expectation gap can only be filled with Forensic Accounting. The similar concept is defined by The Association of Certified Fraud Examiner [7], that financial statement auditors' (i.e., external auditors) are not fraud examiner and also states that, external auditors cannot be considered as the most efficient way to detect or limit fraud.

According to [7] firm and durable corporate governance practices are necessary when owners (shareholders) are not responsible for setting strategy or carrying out business activities, for example publicly traded companies. These corporate governance practices or codes assist preventing fraud and fraudulent activities. These codes can be further strengthened by utilization of the right anti-fraud expertise i.e., Forensic Accounting. Furthermore, [3] stated that aftermath of corporate accounting scandals and the resultant outcry for transparency and reliability in reporting created two outcomes. First is "forensic accounting" and second is "innovation in corporate governance".

Bhasin [8] stated that fraud exists in our society for centuries long. It is estimated that the typical business loses 5 percent of its revenues each year to fraud, this equates to $\$ 50,000$ for every $\$ 1$ million in annual revenues [7]. Such a disastrous situation requires certain additional steps and one of which is acquiring the assistance of Forensic Accounting towards enhancing and strengthening corporate governance. In accordance with [9] Forensic Accounting should be seen as the application of financial skills and investigative mindset conducted with the context to resolve unresolved issues, thus complementing corporate governance in a manner which is not covered by the management's regular devised controls.

\section{A. Background of the Study}

People respond to what is inspected, not what is expected [10]. Several mitigating factors should be available within an organization for the entire internal deficiencies. Such internal mitigating factor reduces the time delay for solutions, prevents additional value loss and multiplies the number of tools available for implementation of solutions. It is widely understood that corporate governance is an internal process and 
majorly persuaded and prompted internally. If internal controls are not strengthened by the use of expertise, then corporate governance is bound to collapse, corporate governance maturity (CGM) will be impossible to achieve and above all, it will also raise the ventures for fraud and embezzlement.

Gee [11] opined that ever changing time requires the new technologies and expertise as the criminals are always one step ahead in thinking and executing the crime. In this regards, the conventional way of fighting or eliminating fraud requires change as well. This change can be defined as Forensic Accounting which is also the necessity and should be considered as an essential requirement for the implementation of good governance and eventually lead towards attainment of CGM. As mentioned by [12] and [13], some tools which were utilized in detecting the fraud were provided and operated by Forensic Accounting which resulted in formation of many governance committees e.g., Committee of Sponsoring Organizations of the Treadway Commission (COSO) and Sarbanes-Oxley Act (SOX).

Forensic Accounting requires providing services which are beyond the general understanding of corporate people. As mentioned by Center for Forensic Studies, it is expected from Forensic Accounting to offer reliefs to shareholders by assisting the conventional auditors. Moreover injecting Forensic Accounting techniques into conventional auditing will be effective to prevent leakages caused by corporate failure, i.e., provide preventive measures to the organization.

\section{B. Research Gap}

Several studies are available which define Forensic Accounting as an institution or person who appears or calls upon after the fact (i.e. when the fraud has actually happened). For instance, $[6,11,14,15,16]$ investigated the role of Forensic Accounting as detection control, litigation expert, and fraud finder.

There are only a few studies available which stressed that Forensic Accounting should be a part of corporate governance. However, there is no study that demonstrates the relationship of Forensic Accounting as a governance management system and as part of organization's management team. In accordance with [17] governance management are those which are directly responsible for the governance of organization, i.e., board of directors, audit and risk committee, governance and compliance committee and internal audit department. On the other hand, [1] and [18], stated that Forensic Accounting is positioned to explore the redesign of corporate governance because of its skills and knowledge. Here the question arises if Forensic Accounting is positioned to redesign corporate governance then why Forensic Accounting cannot become a function of governance management?

Furthermore, there are no specific standards available for Forensic Accounting like Internal and External Auditing. In the absence of these standards, Forensic Accounting as profession is considered as part of audit instead of being considered as a separate standalone body with own standards and practices. Both Institute of Internal Auditors [19] and American Institute of Certified Public Accountants [20] negated the role of identifying the fraud and labeled it as management's responsibility and this role of external auditors as mentioned in [20], is acceptable to Securities and Exchange Commission of United States [2,21].
Further to above, there is no doubt and in accordance with regulatory standards, it is the management's responsibility to identify and report fraud. However, in doing so management requires expertise; which is Forensic Accounting. Even though Forensic Accounting is becoming a necessary part of any organization, it is still not visible within the Codes of Corporate Governance issued by many authorities and regulators including the recent code issued in Oman [22].

Furthermore, the researcher is not able to find specific role of Forensic Accounting towards:

- Supporting organization's operations as risk and fraud compliance testing function.

- Achieving CGM as policy developer, risk assessor, and fraud testing function.

Since the existing literature provides less evidence that attempt to observe the influence of forensic accounting on corporate governance maturity, this paper offers and calls a promising proposition for future research.

The interests of investors and other stakeholders are usually protected by a three-tier security system which comprises of governance codes, second is organization's management and last are the controllers such as auditors [23]. These three tiers lead to one another for the achievement of CGM and on the whole becomes overall process of CGM. If any one of the three tiers is not performing effectively and efficiently, then the whole process could collapse [24]. In accordance with [3], organizations fail to achieve corporate governance and eventually CGM due to following reasons:

- Lack of well formulated and implemented policies and standards of achieving CGM.

- Lack of honesty, integrity and transparency in financial reporting

- Inefficient and ineffective system of risk assessment In accordance with the research gap and problems discussed above, the proposed research questions are: Is there any association between FA and CGM? Is there any relationship between FA and internal auditors? Is there any correlation between internal auditors and CGM? Whether internal audit mediates relationship between Forensic Accounting and CGM?

\section{LITERATURE REVIEW AND THEORETICAL BACKGROUND}

This section will focus on the existing literature relevant to this paper. Review of existing studies will provide strong foundation for understanding that why FA is necessary, how it can strengthen CGM and how internal audit can perform as mediator between FA and CGM? This section will also discuss the theories which support the issues related to enhancement of CGM through Forensic Accounting and internal audit as mediator.

\section{A. Past Studies on CGM}

Given the ever-growing concerns of various stakeholders, corporate governance has transformed from just being a buzz word to a dependable and substantial method to ensure preservation of shareholder's value. In this regard, CGM evolved into an industry's skeptical framework which defines 
the key attributes associated with levels of maturity on the continuum to becoming a better governed organization [24].

There are certain fundamental requirements which are very essential towards CGM. These requirements include legal compliance, accountability, effectiveness, and efficiency of operations and ethical behavior [25]. In accordance with [26], it is the responsibility of senior management and board of directors to act towards achievement of CGM. Board of directors and senior management should act as the focal and central point and also act as the custodians of corporate governance.

Corporate governance itself cannot achieve anything unless certain measuring tools are incorporated to assess its performance and its impact on organization. As mentioned by [27] corporate governance can be tick box compliance or can be properly implemented to achieve business goals. To measure the corporate governance, CGM models are utilized which defines whether organizational governance is heading towards accomplishment of goals or not. In accordance with [24] CGM can assist organizations to identify where corporate governance competencies may be positioned on a maturity range and what are the gaps that exist between actual and planned performance.

CGM is difficult to achieve where there are complex corporate relationships, weak regulatory requirements, weak legal and judiciary system and scarce human resource capabilities [4]. But if it is implemented, controlled and achieved then CGM can ensure developed markets, sound policies and procedures and system of reward and accountability. Assurance is required towards implementation and achievement, whereas elimination of fraud is required for proper control and safeguarding organization's repute. These assurances and eliminations cannot be achieved without IA and assistance of FA [25,28].

CGM is the first step towards understanding where the organization stands regarding corporate governance. The big question here is to identify whether the governance can be measured or not? As stated by [29], the fact that corporate governance encompasses many different kinds of aspects, both 'hard' and 'soft', indicates that perhaps some of them can be measured more easily than the others. In accordance with [30] and [31], since hard aspects coincide largely with aspects of compliance, there may well be a possibility to measure this compliance, whereas, so-called 'soft' aspects (beyond the numbers), which are to be situated largely in the 'control environment', the question is not so easily answered.

There are several tools available for the measurement of governance maturity provided by $[24,32,33,34]$ moreover and as mentioned by [31] any tool which best serves the organizational requirements can be utilized. In governance risk and compliance capability module defined by [35] there are eight elements that need to be measured and this includes principles and critical success factors. If CGM elements are measured properly and deployed effectively, they will result in the following universal outcomes:

- Achieve business objectives.

- Enhance organizational culture.

- Increase stakeholder confidence.
- Prepare and protect organization.

- $\quad$ Prevent, detect, and reduce adversity and weakness.

- Motivate and inspire desired conduct.

- Improve responsiveness and efficiency.

- Optimize social and economic value.

All above outcomes cannot be achieved unless element of fraud is eliminated. For this reason Forensic Accounting plays a major role in the direction of assessment and achievement of CGM. Moreover and in accordance with [26] internal audit is one of the key role players towards the achievement of CGM. It is adequate to mention that CGM is completely dependable on various components, rules, and regulations. From these components, Forensic Accounting and internal audit is one of the crucial and vital functions $[4,8,36]$.

Corporate governance is a system, which provides the platform for organizations to perform in a way which is beneficial to all stakeholders. History is filled with events, where organizations collapse because of poor or nonavailability of corporate governance. Poor corporate governance is referred to a term where corporate governance is present but it's not implemented in a manner which can ensure the achievement of organizational goals, i.e. if it is only utilized as compliance check box. Achievement of CGM in the modern financial and business era is not an extra or choose-able option. CGM is fundamental and primary tool towards raising capital, satisfying shareholders and running business successfully. CGM is essential to all stakeholders including employees, vendors, customers, and bankers. CGM also reduces ambiguity and reassures accountability by encouraging adoption of IA and FA in its system.

\section{B. Past Studies on Forensic Accounting (FA)}

Forensic Accounting is need of an hour and is also essential pillar for all organizations [21]. FA is mainly recognized for detecting financial frauds and for this reason, any study of Forensic Accounting is coarse unless it is combined with fraud and tackling of fraud [37]. Bhasin [38] opined that, FA came into existence because of the continuous and rigorous frauds, which are not detectable by the common auditing tools, additionally, conventional way of auditing is not enough as frauds are still transpiring, despite of the presence of policies, governance codes and governance bodies.

FA is defined by many scholars as integration and amalgamation of auditing, investigative and accounting skills. Eliezer and Emmanuel [39] explained that specialized area within accounting profession is known as Forensic Accounting. Forensic Accounting engagements can be suitable for actual or anticipated quarrels or lawsuits. Forensic means "suitable for use in court of law".Mitrić, Stanković, and Lakićević [40] established that segment which deals with the study of fraud and malfeasance is called Forensic Accounting and person who performs Forensic Accounting is called forensic accountant. The comprehensive definition is defined by [41]:

“...a multidisciplinary field that encourages both $a$ profession and an industry, where civil or criminal economic and financial claims, whether business or personal, are contested within established political structures, recognized and accepted social parameters, and well-defined legal 
jurisdictions, and informed by the theories, methods and procedures from the field of law, auditing, accounting, finance, economics, psychology, sociology, and criminology"

It is necessary to explain here that there is a difference between forensic accountants, fraud auditors, and financial auditors. According to [21] financial auditors are only concerned with the compliance with applicable standards and laws; fraud auditors identify the potential fraud and raise the red flag whereas Forensic Accountants check every area of the potential fraud, identify the reasons, amount, perpetrator and also suggest the way forward and lesson learned.

FA arises from the cause and effect of fraud and technical error made by human [14]. Likewise and as mentioned by [42] the outbreak of occupational fraud and financial abuse has increased pressure on the accounting and or auditing professions to find improved ways of uncovering financial crimes and the answer for such problem is FA [38].

As described by [21] the term forensic accounting refers to the comprehensive view of fraud investigation. It includes preventive measures related to frauds and analyzing anti-fraud controls which are present in organization's system. Enofe, Ekpulu, and Ajala [43] opined that FA could directly influence corporate governance. Similar explanation is defined by [2] that FA can positively impact organizational achievement of goals by eliminating fraud risk and strengthening internal controls. Therefore, it can be asserted that FA plays major role in strengthening corporate governance and achievement of CGM.

Although FA is operating without any regulating standards but its characteristics and skills makes this activity valued and appreciated. Imoniana, Antunes, and Formigoni [44] define skills of FA as comprehensive and enough to impact the achievement of CGM. Moreover, [1,18] stated that Forensic Accounting is positioned to explore the redesign of corporate governance because of its skills and knowledge.

In accordance with [7], the majority of the frauds occur in the category of asset misappropriation, however, they are the lowest in the monetary loss, whereas financial statement fraud is the lowest in frequency, yet it is highest in the median loss. It is worth mentioning that asset misappropriation is controlled and monitored by internal and external auditors, but for detection and prevention of financial statement fraud, FA is required. One of the distinctive features of corporate governance is to present true and fair view of the financial statements and if importance is not given in the area of financial statement fraud, then the survival of corporate governance can be jeopardized or will be at high risk.

In accordance with $[14,16,21,45]$, FA is only invited once the fraud is detected. This paper intends to enhance value of FA as part of governance management where fraud can be prevented before it occurs and FA can further strengthen the internal audit department and also audit committee in order to achieve CGM. A similar concept is mentioned by [2], stating that FA with appropriate education, training, and experience can provide assistance to departments and governance bodies to enhance their functions and responsibilities towards fraud detection and prevention.

In current business environment fraud testing is becoming a requirement. It is an obligation of organization to provide assurance to shareholders and its management that organization's financial statements and operations are free from fraud and FA is the paramount option in providing such assurance. Although there are no standards or regulations for FA, but ever changing business environment created the need for this profession.

FA can be considered as competent specialist to influence IA, especially in case where auditors denied the fact of identifying fraud. FA can be an important aspect of any organization which can assist in achieving CGM and develops effective mitigating controls. Moreover, FA role is not utilized up to its full potential and is only utilized when fraud occurs i.e., as detective control instead of preventive measure.

\section{Internal Audit as Mediator}

In order to achieve CGM, organizations' boards of directors are asserted with responsibility towards maintaining effectiveness of internal control systems. In this case, the internal audit plays vital role in assisting the board to discharge its governance responsibilities [17,46]. Furthermore and in accordance with [47], it is the duty of IA to provide assurance for the effectiveness of organizational operations and governance. In this regards, IA becomes an integral part of corporate governance and also vital tool towards the achievement of CGM.

As mentioned earlier, IA is governed by standards and frameworks. These standards are defined by Institute of Internal Auditors (IIA). In accordance with IIA internal audit is:

"Independent, objective assurance and consulting activity designed to add value and improve an organization's operations. It helps an organization accomplish its objectives by bringing a systematic, disciplined approach to evaluate and improve the effectiveness of risk management, control, and governance processes."

Further to above, management is responsible for controlling risk to ensure that the objectives are met while the scope of internal audit is based on reviewing risk management and internal controls [48].

The major task of IA is to provide assurance [28]. These assurances are directed towards governance, risk and internal controls. Furthermore and in accordance with [25,49], stakeholder expectations related to the roles of IA in assessing and making assurance on governance maturity have increased and IA plays significant role in supporting, planning, assessing, and enhancing CGM. This makes IA an integral part towards providing assurance for CGM and clearly demonstrates that IA has direct relationship with CGM.

Responsibility for CGM falls on an organization's board of directors and its audit committee. IA endorses corporate governance by serving as a resource to the board and the audit committee by providing assurance on control testing, advisory, and organization insight [50]. Similarly and in accordance with [36] IA role in risk management is very crucial but internal audit is either not ready to pursue or is not proactive in pursuing it. However, with the right level of skills and experience, IA will be able to carry out this role very effectively.

Further to above, for the fraud risk, it is opined by [19] that internal auditors must have sufficient knowledge to evaluate the risk of fraud but are not anticipated to have skills and expertise of a person whose primary responsibility is detecting 
and investigating fraud. It is worth mentioning that this expertise and knowledge can be provided by FA. Likewise, inclusion of FA into IA will not only strengthen the CGM but will also complete the IA's process related to risk evaluation, control testing, and auditing procedures.

IA is a key element of the corporate governance structure, contributing to the overall quality of the control environment and internal controls [17]. In current business environment, IA is compulsory CGM component and plays important role in strengthening organizational controls. However major suffering of organizations is due to fraud which is lacking in IA's role. By utilizing FA, fraud risk aspect will be dealt with specialized approach and will also complete the control cycle.

\section{UNDERLYING THEORIES}

In accordance with [51] theories are formulated to explain, predict and understand facts/ events. There are several theories available for corporate governance; however, there are only a few available in the field of Forensic Accounting and internal audit which can directly attribute to this paper. For the purpose of this paper following theories are utilized:

1. Agency Theory

2. Theory of Profession

There are possibilities of other theories to be included in future research; however, directly linked theories are those which are mentioned above. Brief of these theories are mentioned below:

\section{A. Agency Theory}

Agency theory can be defined as shareholders delegate some responsibilities to a team of experts while keeping in mind that they will perform best for the success of their organizations [52]. It is worth mentioning, that success cannot be achieved without attaining CGM. Similar concept is explained by [53] that an agent or agency is hired by one or more person(s), called the principal(s), under a contract and is compensated by the principal to achieve desired outcomes for the principal. Because the agent is acting on behalf of the principal, the principal gives away decision-making authority to the agent. Furthermore, and in accordance with $[4,54]$ agency theory is applied to explain dominant role of agents on corporate governance.

Hired agents are directly responsible for the implementation of corporate governance and achievement of CGM. This clearly demonstrates that corporate governance is entirely dependent upon the agents which are hired by principals. These agents form different committees among themselves to further distribute responsibilities such as board of directors, audit committee and risk committee. In accordance with [55], internal audit directly reports to audit committee and plays vital role concerning organizations governance maturity.

Agency theory defines the relationship between management, shareholders and shareholders' nominated directors. Management is responsible for the delivery of results and safeguarding the interest of shareholders and this interest can only be protected by achieving CGM and utilization of control tools which can be categorized as internal audit and FA.

The focus of corporate governance is security of interest towards stakeholders with specific focus on shareholders. As mentioned by [52] delegation, as per agency theory, creates problems when managers neglect the concerns of their principals (shareholders) and put their self-interests on priority line and start gathering private benefits. In accordance with [14] common mind set behind gathering private benefits is that the agents perform entire task and do not want to provide benefits to shareholders who only invest money and perform no operations. Such kind of behavior requires protection and monitoring which can certainly be provided by FA and IA.

\section{B. Theory of Profession}

Forensic Accounting is a profession and many specialists in other fields are seeking to become professionals in this field [13]. This theory defines how profession should work and what are its peculiarities and attributes. The theory of profession can also be defined as the authority and repute provided by the general public and associations to the profession for protecting public interest. As mentioned by [56], this theory provides an Analytical comprehension which assists in understanding the characteristics, attributes, and structure of the forensic accounting profession.

Above mentioned attributes are utilized to assess the profession of FA, their skills and competence. Assessment is made relating to providing assurance services for stakeholders specially organization's management and shareholders. Although there are no official codes available for Forensic Accounting, however, codes utilized by Chartered Accountants and Certified Internal Auditors can be applicable to profession of FA. Likewise and as informed by [4], that it is essential to employ, train and reward professional managers who can be held to high standards of competency, ethics and responsibility and thus assists in achieving and maintaining CGM.

Internal audit is already well versed in their profession and recognized as major tool in relation to CGM however; if FA is included in internal audit profession then internal audit along with FA will become robust, efficient and effective defense control for the achievement of CGM.

Theories assist in defining conceptual framework and also aiding variables of this paper. Agency theory defines the relationship among principals and agents, additionally, this theory also emphasizes the protection of principal's rights. This protection can be achieved by introducing FA and internal audit which in turns enhances corporate governance and eventually pave the path for achieving CGM. Theory of profession force FA and IA to perform their task in a manner which can assist in protection of public interest. 


\section{PROPOSITION DEVELOPMENT}

After tendering above arguments on FA and IA, it is indeed interesting to further explore the contributions of FA on CGM of public listed companies in Oman. The aim of this proposed research is twofold. It is an ultimate aim that this research should see whether FA improve CGM and also if IA brings positive synergy on the relationship between FA and CGM of public listed companies. If the outcome shows a positive and effective role on an organizational success, then these companies should seriously start considering and adopting a method to identify, manage, measure and utilize FA and IA to its optimum.

\section{A. Forensic Accounting and Corporate Governance Maturity}

FA, if utilized to its full potential, can assist organizations in achievement of CGM [38]. According to [7,21,57], fraud risk is the highest among all risks which adversely impacts organization's ability to achieve CGM and in accordance with [2], FA is best positioned to stamp out the fraud risk.

As mentioned by [52], agency theory defines the concerned and interrelated parties in corporate governance, whereas, theory of profession as mentioned by [58] emphasizes on Analytical comprehension; which assists in understanding the characteristics, attributes and structure of the FA profession. Likewise, theory of profession also emphasizes on maintaining highest ethical standards, professionalism and protection of public interest, therefore, FA can be an agent as mentioned in agency theory and can positively influence corporate governance in achieving CGM.

In accordance with the above, researcher will develop the first proposition:

Proposition 1: Forensic Accounting has a positive association with corporate governance maturity.

\section{B. Forensic Accounting and Internal Audit}

As per [19] and for the adoption of theory of profession, internal audit itself cannot achieve the purpose of this theory, unless, it is equipped with FA techniques and practices. In order to prevent rights of the principals, agency theory and for the purpose of professionalism as mentioned in theory of profession internal audit requires integration with FA. Furthermore and in accordance with [43,59], Forensic Accounting can influence the decision, working and opinion of auditors. These influence can range from establishing need or requirement for fraud testing and investigation, verification of existence or in-existence of fraud and fraud risk compliance adherence.

Based on the above, second proposition would be as follows:

Proposition 2: Forensic Accounting has a positive influence on auditors' opinion.

\section{Internal Audit and Corporate Governance Maturity}

Board of directors and audit committee are the integral part of agency theory [4]. They are also responsible for promoting effective corporate governance system and internal audit function plays a key role in assisting the board and audit committee to discharge their governance responsibilities for the achievement of CGM [46].

As opined by [52,59], agency theory defines concerned and interrelated parties in corporate governance and it also defines the necessity of internal audit as part of governance management. In addition and according to the theory of profession internal audit is required to follow its standards which evidently ensure achievement of CGM [25].

Based on the above, the third proposition would be:

Proposition 3: Internal audit has a positive relationship with CGM

\section{Mediating Proposition}

Mediator or an intervening variable is a type of variable which describes the relationship between an independent and dependent variable [60,61]. Effective and efficient internal audit is undeniably crucial to guarantee CGM and reliable financial reporting that eventually boost the investor's confidence in the capital markets [17,54]. As per the Agency theory, CGM cannot be achieved unless all of its constituents are functioning effectively and efficiently i.e. CGM is dependent on other variables' performance and success.

In line with [62], theory of profession defines that the auditor is responsible for identifying fraud and its related components whereas in accordance with [19] IA requires assistance and expertise of a person who is expert in fraud detection i.e. Forensic Accounting. Thus it could be essential that internal auditor obtains expertise from Forensic Accounting and provides its opinion with prudence which enhances the likelihoods of accomplishing CGM. Therefore, it could be stated that internal audit plays mediator role between Forensic Accounting and CGM.

In similarity to mediating relationship defined by [2] and stated above in proposition 1,2 and 3 , there is positive significant direct relationship between FA and CGM, a positive significant direct link between FA and IA, and a positive significant direct relationship between IA and CGM. For this reason, this study can affirm that IA mediates the relationship between FA and CGM.

From the above mentioned theories the fourth proposition would be:

Proposition 4: IA plays mediating role in the relationship between FA and CGM

\section{CONCEPTUAL FRAMEWORK}

The proposed mediation model is illustrated in Figure 1 below. The model proposes that the independent variable (FA) influences the mediator (IA), which then will influence the dependent variable (CGM). As opined by [63], IA can be examined through its responsibility to ensure business transparency, examining and monitoring effectiveness of internal control and maintain high integrity in their corporate business activities and operations. 


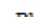

\begin{tabular}{|c|c|c|c|c|}
\hline Forensic Accos unting & $P_{2}$ & Intomal Audit & P3 & $\begin{array}{c}\text { Corporate Governanco } \\
\text { Maturity }\end{array}$ \\
\hline & & & & \\
\hline
\end{tabular}

FIGURE 1. Conceptual Framework

FA is proposed as the independent variable based on the fact of literature and previous research, which reveals that FA can have strong influence on CGM [1,18]. Simultaneously, past research also suggests that FA and IA are interrelated $[19,43,59]$. As mentioned by [64] agency theory suggests a series of procedures to reconcile interest of shareholders and managers. These procedures include monitoring agent's behavior by implementing auditing and other governance instruments; thus it can be substantiated that CGM is dependent variable which can be influenced by IA and FA.

\section{CONCLUSION}

The intention of this study will be to explore potentials to examine the mediating effect of internal audit on FA and CGM as shown in proposed conceptual framework. The issue of corporate frauds, fraud detecting methods, and corporate governance failure is frequently highlighted in several literature. Most literature found is towards addressing the issues on FA skills, FA traits, fraud detection techniques, managing corporate governance, and also on FA and CG definitions. However, researcher was not able to find particular attempt to investigate FA as preventive measure for CGM with IA as mediator hence making this paper's propositions unique.

Distinctive role of FA is expected to set immense influence on achieving CGM. Hence, this is an indication that FA must be deployed in a manner to ensure that its properties are identified and optimized to achieve business goals and improve CGM. FA alongside with IA and with its own innovativeness, creativity, skills, and knowledge provides potential for excellent operational system, well controlled policies and eventually would result into a positive impact on profitability, business sustainability, and integrity.

Why investigate mediating role? It is mainly because there is great possibility that the relationship between FA and CGM is not exclusively direct. Conceptually, Internal Audit is a process by which an organization secures assurance that the risk exposures it could face is understood and managed appropriately. Moreover and in the absence of specific standards, it is believed that the effectiveness of FA and its utilization is driven by the effectiveness of internal audit function.

Notably, this paper positions itself in extending previous studies on FA to a new perspective by incorporating its preventive role towards strengthening corporate governance maturity. This is expected to contribute and bring new insights and views on FA which have not been explored before. This should offer vast opportunities for future researchers to investigate further via diverse perspective pertaining to FA. Furthermore, this paper expects that the proposed theoretical framework developed will be extended to an empirical phase following this paper.

\section{References}

[1] Bhasin, M. L, Corporate Governance and Forensic Accountant: an Exploratory Study. Journal of Accounting - Business \& Management Vol. 20, Issue 2, pp. 55-83, 2013.

[2] Johnson, P., Ayoib, C.-A. R., and Shamsiah, S, Forensic Accounting and Fraud: Capability and Competence Requirements in Malaysia. Journal of Modern Accounting and Auditing., Vol. 10 Issue 8. pp 825-834, 2014.

[3] Vinita, R. Corporate Governance and the Forensic Accountant. The CPA Journal. Volume 75 Issue 3. pp 68-78, 2005.

[4] Fernando, A, Corporate Governance: Principles, Policies and Practices. Pearson, 2009.

[5] Fan, J. P., and Wong, T. J, Do External Auditors Perform a Corporate Governance Role in Emerging Markets? Evidence from East Asia. Journal of Accounting and Research. Vol 43 Issue 1. pp 35-72, 2005

[6] Adedire, T. O, Relationship between Forensic Accountants' Competences and Audit Expectation Gap: Evidence from Nigeria Money Deposit Banks. Jomo Kenyatta University of Agriculture and Technology, Nairobi, Kenya, 2016.

[7] ACFE, Report to the Nations on Occupational Fraud and Abuse. ACFE Magazine, 2016.

[8] Bhasin, M. L, Integrating Corporate Governance and Forensic Accounting: A Study of an Asian Country- International Journal of Management Sciences and Business Research, Vol. 6, Issue 1. pp 31-52, 2017.

[9] Jafaru Jimoh, Philipa O. Idogho, and Francis O. Iyoha (2012). Corporate Governance and Ethical Sensitivity of Directors of Listed Companies: Evidence from Nigeria. Global Journal of Management Science and Technology Vol. 1 Issue. 3. pp 20-28

[10] Munshi, A, Performance Management Based On The Balanced Scorecard, Institute of Internal Auditors, Oman Chapter Conference Presentation, 2016.

[11] Gee, S, Fraud and Fraud Detection: A Data Analytics Approach. John Wiley \& Sons, Inc., Hoboken, New Jersey, 2014.

[12] Baird, J., and Zelin, R, An examination of the impact of obedience pressure on perceptions of fraudulent acts and the likelihood of committing occupational fraud. Journal of Forensic Studies in Accounting and Business, Statesboro, GA: Center for Forensic Studies in Accounting and Business, Georgia Southern University, Volume 1, No 1, 1-14, 2009.

[13] Bhasin, M. L, Corporate Governance and Forensic Accountants' Role: Global Regulatory Action Scenario - International Journal of Accounting Research Vol. 1, No.1.pp 54-86, 2013.

[14] Adrian, N. K., Lawrence, A., and Cristal Lee, A. S, Forensic Accounting: Public Acceptance towards Occurrence of Fraud Detection. International Journal of Business Management, Vol. 4, No 11, pp.145-150, 2009.

[15] Leo, M., and Stephen, O, Introduction to Forensic Accounting The Story behind the Numbers. Financial Executive International RSM, 2015.

[16] Nigrini, M. j, Benford's Law Applications for Forensic Accounting, Auditing, and Fraud Detection. John Wiley \& Sons, Inc., Hoboken, New Jersey, 2012.

[17] Hermanson, H. M., and Rama, D. B, Pressure on Internal Auditors to Alter Findings. Journal of Forensic \& Investigative Accounting. Vol 8 Issue 2. pp 241-256, 2016.

[18] Ali, M., and Oseni, Corporate Governance, Transparency And Shareholders' Rights: The Role Of The Forensic Accountants In 
Propelling Economic Growth. Multidisciplinary Journal of Research Development, Volume 15, No 1, 2010.

[19] IIA, I. o,. Internal Auditing and Fraud. The Institute of Internal Auditors-IPPF Practice Guide, 2016.

[20] American Institute of Certified Public Accountants - AICPA, Generally Accepted Auditing Standards GAAS. AICPA, 2013.

[21] Singleton, T., and Singleton, A, Fraud Auditing and Forensic Accounting 4th Edition. Chicago: John Wiley \& Sons, 2010.

[22] Capital Market Authority-CMA, Oman Code of Corporate Governance for Public Listed Companies. Capital Market Authority, 2016.

[23] Bhasin, M. L, Communion of Corporate Governance and Forensic Accounting: A Study of an Asian Country- British Journal of Research, 10 (4), pp 143-162, 2016.

[24] Deloitte, T, The centre for corporate governance: Board Leadership. Deloitte \& Touche LLP Internal Audit Professionals, 2010.

[25] IIA Research Foundation, Improving Organizational Governance through Implementing Internal Audit Standard 2110. IIA Research Foundation,2011.

[26] Wilkinson, N., and Plant, K, A framework for the development of an organizational governance maturity model: a tool for internal auditors. Southern African Journal of Accountability and Auditing Research Vol 13 Issue 1. pp 19-31, 2012.

[27] Mazars, EcoDa, and Ecgen, Corporate Governance codes should avoid becoming a 'tick- box' exercise and encourage a longer term view of business performance. Mazars, 2015.

[28] Roth, James, Best Practices: Evaluating the Corporate Culture. Institute of Internal Auditors Research Foundation (IIARF), 2010

[29] Cattrysse, J, Reflections on Corporate Governance and the role of the internal auditor. Roularta Media Group.pp 1-64, 2005.

[30] Meredith, E., and Robyn, C, Corporate Governance and Performance: An Exploration of the Connection in a Public Sector Context. University of Canberra, 2005.

[31] Roberta, R., Sanjai, B., and Brian, B, The Promise and Peril of Corporate Governance Indices. Yale Law School; Yale Law School Legal Scholarship Repository. Vol 8 Issue 8. pp 1803-1882, 2008.

[32] OECD, Risk Management and Corporate Governance, Corporate Governance, OECD Publishing, 2014.

[33] Committee of Sponsoring Organizations of the Treadway Commissions (COSO, Enterprise Risk Management: Aligning risk with strategy performance. Committee of Sponsoring Organizations of the Treadway Commissions, 2016.

[34] OECG, Red Book GRC Capability Model Version 2.1, OECG publishing, 2012.

[35] Switzer, C. S., Mitchell, S. L., and Mefford, J. L, Governance Risk Compliance Capability Model Version 3. OECG. Volume 1 Issue 3, 2015.

[36] Griffiths, P, Risk Based Auditing. Ashgate Publishing Group, 2005.

[37] Leonard, Fraud Testing in Audit Program. Muscat, 2016.

[38] Bhasin, M. L, Contribution of Forensic Accounting to Corporate Goverance: An Exprolatory Study of an Asian CountryInternational Business Management 10(4), pp 479-492, 2016.

[39] Eliezer, O., and Emmanuel, B, Relevance of Forensic Accounting in the Detection and Prevention of Fraud in Nigeria. International Journal of Accounting Research Vol. 2, No. 7,pp 17-25, 2015.

[40] Mitrić, M., Stanković, A., and Lakićević, A, Forensic Accounting - the Missing Link in Education and Practice. Management Journal for Theory and Practice Management. Issue 65. pp 41-56, 2012.

[41] Wm. Dennis, H and James A, D, Research in Forensic Accounting - What Matters. Journal of Theoretical Accounting Research. Vol 9 Issue 2. pp 40-70, 2014.

[42] Effiok, S. o., and Eton, o. e, Ensuring quality control of forensic accounting for efficient and effective corporate management. Global journal of social sciences vol 12. pp 27-33, 2013.
[43] Enofe, A., Ekpulu, G., and Ajala, T. O, Forensic Accounting and Corporate Crime Mitigation. European Scientific Journal edition vol.11, No.7, 2015.

[44] Imoniana, J. O., Antunes, M. T., and Formigoni, H, The forensic accounting and corporate fraud. JISTEM J.Inf.Syst. Technol. Manag. vol.10 Issue1. pp 119-144, 2013.

[45] Charles, D., Ramona, F., and Suzanne, O, Characteristics and Skills of the Forensic Accountant. American Institute of Certified Public Accountants, 2009.

[46] Florea, R., and Florea, R, Internal Audit and Corporate Governance. Economy Transdisciplinarity Cognition. Vol 16 Issue 1. pp 79-83, 2013.

[47] International Organization of Supreme Audit Institutions, The International Standards of Supreme Audit Institutions; The Auditor's Responsibilities Relating to Fraud in an Audit of Financial Statements. International Organization of Supreme Audit Institutions, 2016.

[48] Pickett, K. H, The Essential Guide to Internal Auditing, 2nd Edition. A John Wiley \& Sons, Ltd Publication, 2011.

[49] IFA, I. F, International standard on auditing 240: the auditor's responsibilities relating to fraud in an audit of financial statements. International Federation of Accountants, 2009.

[50] Mahd Ali Al- Jabali, Osama Abdalmanam, Khalifeh N. Ziadat, Internal Audit and its Role in Corporate Governance. Middle Eastern Finance and Economics. Issue 11. pp 161-176, 2011.

[51] Swanson, R. A., and Chermack, T. J,. Theory Building in Applied Disciplines. Berrett-Koehler Publishers, 2013.

[52] Afza, T., and Nazir, M. S, Theoretical Perspective of Corporate Governance: A Review. European Journal of Scientific Research, Vol. 119, No 2, pp. 255-264, 2014.

[53] Miles, J. A, Management and Organization Theory. Wiley, 2012.

[54] Earnest, D. F., and Sofian, S, The Mediating Role of Corporate Governance on Intellectual Capital and Corporate Performance. Journal of Economics, Business and Management, Vol. 1, No. 4,pp 339-343, 2013.

[55] IIA Research Foundation, I, Internal Audit reporting relationships: serving two masters. IIA Research Foundation, IIARF, 2003.

[56] Chen, Y., and Akkeren, J. V, The Theory of Profession: Accountability, qualifications, entry and ethics - a preliminary discussion and early findings on the current state of forensic accountancy in Australia, 2013.

[57] Eyisi, A. S., and Ezuwore, C. N, The Impact of Forensic Auditors in Corporate Governance. Research Journal of Finance and Accounting, Vol.5, No.8. pp 31-39, 2014.

[58] Candilis, P, The Revolution in Forensic Ethics: Narrative, Compassion, and a Robust Professionalism. Psychiatric Clinics of North America. Vol 32 Issue 2. pp 423-435, 2009.

[59] Micheal. B. Adams, "Agency Theory and the Internal Audit", Managerial Auditing Journal, Vol. 9 Issue: 8, pp.8-12,1994.

[60] Sekaran, U, Research Methods for Business: A Skill-Building. John Wiley \& Sons, Inc, 2003.

[61] Wu, A. D., and Zumbo, B. D, Understanding and Using Mediators and Moderators. Social Indic Research, vol. 8, no. 7. pp 367-392, 2008

[62] Sijpesteijn, F. K, The value relevance of auditors' communications financial statement users' understanding of the messages in the audit report. Erasmus Universiteit Rotterdam, 2011.

[63] Alic, M., and Rusjan, B, Contribution of the ISO 9001 internal audit to business performance. International Journal of Quality \& Reliability Management, Volume 27 Issue: 8, pp. 916-937, 2010.

[64] Roslan, A., and Dahan, H. M, Mediating Effect of Enterprise Risk Management on Internal Audit and Organizational Performance: A Conceptual Framework. International Journal of Commerce, Business and Management (IJCBM). Volume 2 Issue 4. pp 212215, 2013. 